\title{
PENERAPAN MODEL PROBLEM BASED LEARNING DALAM PEMBELAJARAN SEJARAH UNTUK MENINGKATKAN HASIL BELAJAR SISWA DI SMA ERLANGGA PEMATANGSIANTAR
}

\author{
Ahmad Fakhri Hutauruk \\ Program Studi Pendidikan Sejarah, Universitas Simalungun, Indonesia \\ Email: fakhrispd@gmail.com
}

\begin{abstract}
This article discusses the application of the problem based learning model in history learning in the XI IPS class at SMA Erlangga Pematangsiantar, as well as its influence on students' historical learning outcomes. The research method used is classroom action research conducted with 2 cycles. Data collection uses observation sheet instruments, interviews, written tests, field notes, and student worksheets. The results showed that the application of the problem based learning model in historical learning was able to improve student learning outcomes. This is indicated by the value obtained by students in each cycle. In the first cycle, the average value of student activity reached 71, while the learning outcomes got an average value of 69. In the second cycle, the average value of the activity and student learning outcomes increased. The average value of activity reaches 75 , while the average value of learning outcomes reaches 80 .
\end{abstract}

Keywords: Learning Outcomes, Learning Model, Problem Based Learning

\begin{abstract}
Abstrak
Artikel ini membahas tentang penerapan model problem based learning dalam pembelajaran sejarah di kelas XI IPS SMA Erlangga Pematangsiantar, serta pengaruhnya terhadap hasil belajar sejarah siswa. Metode penelitian yang digunakan adalah penelitian tindakan kelas yang dilakukan dengan 2 siklus. Pengumpulan data menggunakan instrumen lembar observasi, wawancara, tes tertulis, catatan lapangan dan lembar kerja siswa. Hasil penelitian menunjukkan bahwa penerapan model problem based learning dalam pembelajaran sejarah mampu meningkatkan hasil belajar siswa. Hal ini ditunjukkan dengan nilai yang diperoleh siswa pada setiap siklus. Pada siklus I, rata-rata nilai keaktifan siswa mencapai 71 , sedangkan hasil belajarnya mendapat nilai rata-rata 69. Pada siklus II, nilai rata-rata keaktifan dan hasil belajar siswa mengalami peningkatan. Nilai rata-rata keaktifannya mencapai 75 , sedangkan nilai rata-rata hasil belajarnya mencapai 80.
\end{abstract}

Kata Kunci: Hasil Belajar, Model Pembelajaran, Problem Based Learning 


\section{PENDAHULUAN}

Pembelajaran adalah proses belajar yang dibangun oleh guru untuk membimbing peserta didik agar dapat mengembangkan kreativitas berfikir dan mampu mengkonstruksi pengetahuan baru sebagai upaya meningkatkan penguasaan terhadap materi pelajaran (Sagala, 2010: 62). Proses pembelajaran merupakan penentu utama keberhasilan pendidikan, karenanya guru dituntut untuk mampu membangun proses pembelajaran yang efektif supaya siswa mencapai hasil belajar yang maksimal (Hermawan, 2018: 2). Agar proses pembelajaran berjalan efektif, maka guru harus mampu menggunakan beragam model pembelajaran.

Akan tetapi, pelaksanaan pembelajaran di banyak sekolah masih belum berjalan efektif. Kenyataan ini seringkali ditemui dalam pembelajaran sejarah. Proses pembelajaran sejarah yang kini berlangsung di banyak sekolah cenderung kering, tidak menarik dan membosankan (Purnamasari \& Wasino, 2011: 202-203). Salah satu sekolah yang mengalami kondisi tersebut adalah Sekolah Menengah Atas (SMA) Erlangga Pematangsiantar, Sumatera Utara. Hasil observasi penulis menunjukkan bahwa proses pembelajaran sejarah yang dilakukan di kelas XI IPS SMA Erlangga berlangsung sangat monoton. Guru terlihat lebih aktif daripada siswa sehingga proses pembelajaran berjalan satu arah. Hal ini terjadi karena guru masih menerapkan model pembelajaran konvensional. Guru hanya menggunakan metode ceramah dalam menyampaikan materi pelajaran, sehingga ia menjadi satusatunya sumber informasi di kelas. Sementara itu, siswa hanya mendengar dan mencatat materi yang disampaikan oleh guru. Pengunaan model pembelajaran yang konvensional membuat siswa cenderung pasif dan tidak kreatif. Akibatnya, hasil belajar siswa tidak memuaskan.

Menurut Suryadi (2012: 83), faktor-faktor yang menyebabkan pembelajaran sejarah tidak menarik dan membosankan adalah kebijakan pemerintah yang cenderung memarginalkan pembelajaran sejarah, materi pelajaran yang cu- kup banyak dan kompetensi guru yang rendah, serta minimnya minat siswa terhadap mata pelajaran sejarah. Siswa menganggap mata pelajaran sejarah sebagai pelajaran hafalan karena mereka cenderung dituntut untuk menghapal peristiwa-peristiwa masa lalu. Bahkan mata pelajaran sejarah sering kali ditempatkan pada jam terakhir pelajaran, ketika kondisi siswa sudah lelah, sehingga motivasi belajarnya berkurang. Akibatnya, substansi mata pelajaran sejarah tidak tersampaikan dengan baik dan hasil belajar siswa cenderung tidak memuaskan.

Rendahnya prestasi belajar sejarah siswa akan memunculkan generasi muda yang "buta sejarah" bangsanya (Tanjung, 2015: 262). Padahal pelajaran sejarah di sekolah berperan penting dalam menumbuhkan rasa nasionalisme dan cinta tanah air. Bahkan pendapat Walsh yang dikutip Hutauruk (2014: 13) menekankan bahwa nilai-nilai masa lalu yang diajarkan dalam mata pelajaran sejarah dapat membentuk siswa menjadi warga negara yang arif dan bijaksana.

Menurut Isjoni (2007), pembelajaran sejarah di sekolah bertujuan untuk membangun kepribadian dan sikap mental anak didik, menanamkan nilai-nilai kejujuran dan kebijaksanaan kepada peserta didik, serta membangun rasa cinta tanah air dan sikap kemanusiaan. Pembelajaran sejarah berguna untuk membantu siswa mengenal dirinya, budayanya dan budaya orang lain, ikut berpartisipasi dalam kehidupan bermasyarakat, membuat keputusan yang bertanggung jawab pada tingkat pribadi dan sosial, serta mampu menggunakan kemampuan analisis dan imajinatif yang ada dalam dirinya.

Agar tujuan dan kegunaan pembelajaran sejarah dapat tercapai, maka guru ditunut untuk memiliki kemampuan menerapkan beberapa model pembelajaran. Salah satu model pembelajaran yang dapat meningkatkan respon dan minat siswa terhadap pelajaran sejarah adalah model pembelajaran berbasis masalah atau problem based learning. Menurut Padmavathy \& Mareesh (2013: 5-51), problem based learning adalah proses pembelajaran dengan cara 
memberikan permasalahan yang harus diselesaikan siswa dan permasalahan tersebut dapat membantu mereka mengkonstruksi pengetahuan baru. Sementara itu, Cozzola (2008) mengemukakan bahwa problem based learning merupakan pembelajaran yang berpusat pada peserta didik dengan pendekatan masalah pada analisis, pemecahan dan diskusi tentang masalah yang diberikan. Jadi, esensi problem based learning adalah memberikan berbagai masalah yang autentik dan bermakna kepada siswa yang dapat berfungsi sebagai batu loncatan untuk investigasi dan penyelidikan (Tan, 2009: 7).

Arends (2007: 381) menekankan bahwa problem based learning memiliki lima ciri. Pertama, pengajuan masalah atau pertanyaan yang penting bagi siswa. Masalah yang diajukan harus autentik, jelas, mudah dipahami, luas dan sesuai dengan tujuan pembelajaran, serta bermanfaat. Kedua, fokus interdisipliner. Masalah yang diajukan kepada siswa hendaknya mengaitkan atau melibatkan berbagai disiplin ilmu. Ketiga, investasi autentik. Siswa dituntut untuk menganalisis dan merumuskan masalah, mengembangkan dan meramalkan hipotesis, mengumpulkan dan menganalisis informasi, melaksanakan eksperimen, membuat kesimpulan dan menggambarkan hasil akhir. Keempat, menghasilkan dan memamerkan hasil karya. Siswa diharuskan untuk menghasilkan suatu karya, menunjukkan dengan cara menjelaskan dan mempresentasikan karya. Kegiatan presentasi membantu siswa mengembangkan keterampilan berkomunikasi. Kelima, kolaborasi atau bekerjasama. Problem based learning mengarahkan adanya kerjasama antarsiswa dalam menyelesaikan masalah, sehingga siswa dapat mengembangkan kemampuan inkuiri, serta keterampilan berfikir dan berdialog.

Lebih lanjut Arends (2007: 158-169) mengemukakan bahwa tujuan utama pengembangan model problem based learning adalah: a) membantu siswa mengembangkan kemampuan berfikir dan kemampuan pemecahan masalah (problem solving), b) mendewasakan siswa melalui pengalaman mereka dengan dunia nyata dan simulasi masalah, serta 3) membuat siswa mandiri dan menjadi pembelajar bagi diri sendiri. Dengan begitu, penerapan problem based learning dalam proses pembelajaran sejarah di sekolah tentunya dapat meningkatkan motivasi belajar siswa sehingga mata pelajaran sejarah tidak lagi menjadi pelajaran yang membosankan.

Peningkatan motivasi bejalar siswa dalam proses pembelajaran sejarah akan berbanding lurus dengan hasil belajar mereka. Hasil belajar merupakan kemampuan siswa dalam bentuk keterampilan dan perilaku yang diperoleh setelah mengikuti proses belajar (Tanjung, 2015: 262). Gagne \& Buliner (2002) mengklasifikasi hasil belajar ke dalam lima kelompok kemampuan, yaitu: 1) informasi verbal, 2) keterampilan intelektual, 3) strategi kognitif, 4) keterampilan motorik, dan 5) sikap.

Berdasarkan latar belakang di atas, pokok permasalahan yang hendak dikaji dalam artikel ini adalah pengaruh model pembelajaran berbasis masalah atau problem based learning terhadap hasil belajar sejarah siswa di kelas XI IPS SMA Erlangga Pematangsiantar. Dari pokok permasalahan tersebut, muncul pertanyaan-pertanyaan berikut: bagaimana menerapkan model problem based learning dalam proses pembelajaran sejarah di SMA Erlangga Pematangsiantar? Apakah prestasi belajar sejarah siswa mengalami peningkatan setelah diterapkan model problem based learning? Kajian ini diharapkan menjadi sumber inspirasi bagi guru-guru sejarah dalam mengelola proses pembelajaran sebagai upaya meningkatkan prestasi belajar sejarah siswa.

\section{METODE PENELITIAN}

Kajian ini menggunakan metode penelitian tindakan kelas (classroom action research). Menurut Kasbolah (1998), penelitian tindakan kelas adalah suatu upaya guru atau praktisi dalam bentuk berbagai kegiatan yang dilakukan untuk memperbaiki dan meningkatkan mutu pelaksanaan pembelajaran di kelas. Penelitian 
tindakan kelas terdiri dari empat rangkaian kegiatan yang dilakukan dalam siklus berulang, yaitu perencanaan, tindakan, pengamatan dan refleksi (Arikunto, dkk., 2006).

Penelitian dilakukan di SMA Erlangga yang berada di Kota Pematangsiantar, Propinsi Sumatera Utara. Penelitian berlangsung pada Tahun Ajaran 2018/2019. Subyek penelitian adalah siswa kelas XI IPS yang berjumlah 24 orang, dengan rincian 16 siswa laki-laki dan 8 siswa perempuan.

Pengumpulan data dilakukan dengan menggunakan instrumen sebagai berikut: 1) lembar observasi; 2) wawancara; 3) tes tertulis; 4) catatan lapangan; dan 5) Lembar Kerja Siswa (LKS). Tehnik analisis data dilakukan dengan dua tahapan. Pertama, analisis terhadap perencanaan pembelajaran berdasarkan langkahlangkah model problem based learning, yaitu apersepsi, eksplorasi, diskusi dan penjelasan konsep, serta pengembangan dan aplikasi konsep. Kedua, analisis terhadap pelaksanaan pembelajaran yang meliputi aktivitas guru dan siswa dengan menggunakan langkah-langkah model problem based learning, yaitu mengungkapkan konsep awal siswa, berdiskusi kelompok, berdiskusi di kelas dengan melaporkan hasil kerja kelompok dan mengaplikasikan konsep.

\section{HASIL DAN PEMBAHASAN}

Dari wawancara dengan guru yang mengajar mata pelajaran sejarah di kelas XI IPS SMA Erlangga Pematangsiantar diperoleh informasi bahwa siswa yang dapat dikategorikan pandai hanya 5 orang atau $21 \%$, sedangkan siswa dengan kategori sedang mencapai 10 orang atau $42 \%$, dan siswa yang kurang pandai berjumlah 9 orang atau 33\%. Data tersebut menunjukkan bahwa hasil belajar sejarah siswa masih sangat rendah. Hal ini didukung pula oleh nilai rata-rata ulangan harian siswa yang hanya mencapai 68 . Bahkan hasil ujian akhir di semester ganjil hanya mencapai nilai rata-rata 70. Nilai yang diperoleh siswa masih berada di bawah nilai KKM
(Kriteria Ketuntasan Minimal) yang seharusnya mencapai 73.

Rendahnya prestasi belajar sejarah siswa kelas XI IPS SMA Erlangga Pematangsiantar disebabkan oleh model pembelajaran yang kurang menarik. Hasil observasi yang peneliti lakukan menunjukkan bahwa siswa kurang aktif saat mengikuti proses pembelajaran karena mereka hanya mendengarkan penjelasan guru. Bahkan separuh waktunya digunakan untuk mencatat materi yang disampaikan oleh guru. Model pembelajaran seperti ini membuat siswa merasa bosan dan cenderung melakukan kegiatan yang mengganggu proses pembelajaran, seperti bermain-main dan mengobrol.

Berdasarkan hasil wawancara dan observasi di atas, maka peneliti yang berperan sebagai guru pengganti berupaya menerapkan model pembelajaran problem based learning dalam proses pembelajaran sejarah di kelas XI SMA Erlangga Pematangsiantar dengan harapan dapat meningkatkan hasil belajar sejarah siswa.

\section{Analisis Hasil Siklus I}

Penelitian siklus I dilaksanakan pada minggu kedua bulan Februari 2019. Pelaksanaan siklus I menghasilkan beberapa temuan esensial yang diperoleh melalui lembar observasi, catatan lapangan, hasil pembelajaran siswa dan hasil wawancara. Temuan-temuan penelitian siklus I dijadikan sebagai acuan untuk menganalisis data. Analisis data dilaksanakan untuk memperoleh gambaran tentang hasil belajar siswa setelah mereka mengikuti pembelajaran sejarah dengan model problem based learning.

Adapun temuan yang diperoleh pada saat mengawali pembelajaran adalah molornya waktu untuk membuka pembelajaran karena ada dua siswa yang berkelahi. Peneliti segera melerai kedua siswa yang berkelahi, kemudian mereka berdamai dan berjanji untuk tidak lagi mengulangi perbuatannya. Setelah kondisi kelas kondusif, peneliti memulai pembelajaran dengan berdoa terlebih dahulu, kemudian mengucapkan salam dan mengabsen siswa. Peneliti menga- 
lihkan perhatian siswa dan menciptakan kondisi belajar mengajar yang efektif. Sebagaimana yang dijelaskan oleh Usman (2002) bahwa kondisi belajar mengajar yang efektif adalah adanya minat dan perhatian siswa dalam belajar. Dengan demikian, peneliti terlebih dahulu mengkondisikan semua siswa agar dapat mengikuti proses belajar dengan baik.

Selanjutnya, peneliti menggali pengetahuan awal siswa dengan mengajukan beberapa pertanyaan. Salah satunya pertanyaan yang peneliti ajukan adalah seputar materi tentang kolonialisme dan imperialisme bangsa Barat di Indonesia. Siswa lebih aktif dalam mengungkapkan pendapatnya.

Pada tahap eksplorasi, proses pembagian kelompok siswa tidak terlalu ribut karena peneliti menggunakan kelompok yang sudah disusun oleh guru pamong.

Sementara pada tahap diskusi dan penjelasan konsep, siswa lebih aktif dalam menanggapi. Walaupun ada seorang siswa yang sebelumnya selalu aktif menanggapi, tiba-tiba pasif. Ternyata siswa tersebut sedang dalam kondisi kurang sehat. Siswa berubah menjadi aktif dikarenakan motivasi yang peneliti berikan. Dengan memberikan penghargaan atas setiap prestasi dan kebaikan yang dilakukan siswa, sekecil apapun itu dapat membangun citra diri siswa (Sukadi, 2006).

Pada tahap pengembangan konsep dan aplikasi, peneliti melakukan proses tanya jawab dengan siswa untuk bersama-sama menyimpulkan materi yang telah dibahas. Siswa sangat antusias, terbukti dari siswa yang menyuruh temannya yang sedang mengobrol untuk diam. Bahkan dari analisis hasil penilaian pada siklus I menunjukkan nilai keaktifan siswa rata-rata mencapai 71. Meskipun begitu, nilai rata-rata hasil belajar siswa rendah, hanya 69,72 atau berada di bawah nilai KKM.

Dari hasil wawancara dengan siswa diperoleh informasi bahwa mereka merasa senang dengan model pembelajaran yang baru karena mereka dapat memahami materi dengan mudah dan dapat menjawab setiap pertanyaan dari guru. Adapun kesulitan yang dihadapi siswa adalah adanya satu pertanyaan yang membuat siswa berfikir lebih lama. Hasil siklus I ini memberikan masukan kepada peneliti untuk menambah metode dan model pembelajaran yang lain agar lebih bervariasi dan mendapatkan hasil belajar siswa yang memuaskan.

\section{Refleksi Siklus I}

Dari berbagai temuan dari siklus I terdapat beberapa hal sebagai refleksi atas tindakan pada siklus I. Pertama, Berdasarkan hasil observasi kemampuan guru, maka dapat dilihat bahwa guru belum begitu maksimal menerapkan model pembelajaran problem based learning pada pelajaran sejarah dengan tema kolonialisme dan imperialisme bangsa Barat di Indonesia.

Kedua, hasil observasi kemampuan guru dalam siklus I belum begitu baik, di mana dalam memotivasi siswa, menampilkan gambargambar, membimbing diskusi kelompok, mengelola waktu dalam berdiskusi dan persentasi, masih pada kategori baik karena hasil observasi kemampuan guru dalam pembelajaran masih berada di bawah nilai 85 .

Ketiga, berdasarkan hasil tes siswa pada siklus I hasil belajar siswa belum tuntas, dimana dari 24 siswa hanya sebanyak 14 siswa $(58,33 \%)$ yang tuntas belajar secara klasikal, dengan nilai rata-rata siswa pada siklus I sebanyak 69 yang masih dibawah KKM yaitu 73.

Keempat, belum begitu baiknya hasil belajar siswa dapat dimaklumi karena model pembelajaran yang diterapkan oleh guru masih sangat baru bagi siswa. Artinya, sebelumnya siswa belum pernah belajar dengan cara atau dengan metode yang digunakan oleh guru, yaitu model pembelajaran problem based learning.

Berdasarkan uraian di atas dapat dikatakan bahwa kemampuan guru maupun kemampuan siswa dan hasil belajar siswa yang belum begitu memuaskan membuat belum tercapainya target atau indikator yang diharapkan. Oleh karena itu, 
penelitian tindakan ini perlu dilanjutkan pada siklus II.

\section{Analisis Hasil Siklus II}

Siklus II dilakukan pada minggu ketiga bulan 19 Februari 2019. Adapun temuan yang telah diperoleh saat mengawali pembelajaran adalah peneliti membuka pembelajaran dengan berdoa terlebih dahulu, salam dan mengabsen siswa. Pada tahap apersepsi untuk menggali pengetahuan siswa, peneliti mengajukan beberapa pertanyaan yang terkait dengan materi yang telah dibahas pada pertemuan sebelumnya. Dalam tahap ini siswa terlihat aktif mengungkapkan pendapatnya. Suasana pembelajaran menjadi lebih "hidup" dan menyenangkan. Proses pembelajaran berjalan sesuai dengan yang diharapkan oleh peneliti. Selanjutnya, tahap eksplorasi dilakukan dengan mengerjakan tugas kelompok. Kerjasama masing-masing kelompok masih terlihat kurang kompak, tetapi seluruh tugas tetap diselesaikan tepat waktu.

Tahap diskusi dan penjelasan konsep dilakukan di dalam kelas pada saat proses pembelajaran berlangsung. Diskusi berjalan dengan lancar dan siswa sangat aktif dalam memberikan pertanyaan maupun tanggapan. Meskipun begitu, masih ada siswa yang belum ikut terlibat secara keseluruhan. Selanjutnya, pada tahap aplikasi dan pengembangan konsep, siswa mengerjakan tugas individu dengan tertib dan lancar. Siswa lebih semangat dalam menjawab soal-soal. Hal ini terjadi karena siswa sudah memiliki pengetahuan yang lebih mendalam tentang materi yang telah dibahas. Adapun hasil penilaian pada siklus II, yaitu nilai keaktifan siswa rata-ratanya mencapai 75 . Sementara itu, nilai rata-rata hasil belajar siswa mencapai 80. Dengan demikian, hasil belajar siswa sudah melewati nilai KKM.

Dari wawancara dengan siswa diperoleh informasi bahwa siswa sangat senang dengan proses pembelajaran yang mereka diikuti. Adapun kesulitan yang dihadapi adalah masih terdapat siswa yang malu untuk bertanya kepada kelompok yang lain karena ia takut salah. Padahal dengan mengajukan pertanyaan dapat membantu siswa untuk melatih mental sekaligus mendapatkan jawaban atas pertanyaannya yang diajukannya.

Berdasarkan temuan-temuan yang diperoleh dari siklus I dan II dapat dikatakan bahwa model pembelajaran yang digunakan di kedua siklus sudah sangat baik. Meskipun begitu, dalam mengembangkan dan mengaplikasikan konsep tidak harus selalu dengan tes tertulis, tetapi dapat pula dilakukan dengan tes lisan. Hal ini tidak dilakukan oleh peneliti karena membutuhkan waktu yang banyak.

\section{Refleksi}

Dari temuan-temuan siklus II terdapat beberapa hal yang dapat direfleksi. Pertama, hasil observasi terhadap kemampuan guru menunjukkan bahwa guru sudah sangat maksimal menerapkan model problem based learning dalam pembelajaran sejarah dengan materi kolonialisme dan imperialisme bangsa Barat di Indonesia.

Kedua, hasil observasi menunjukkan bahwa kemampuan guru dalam mengelola kegiatan pendahuluan dan kegiatan inti, manajemen waktu dan pengelolaan kelas sudah sangat baik.

Ketiga, hasil tes siswa pada siklus II menunjukkan hasil yang memuaskan, di mana $87,50 \%$ dari 24 siswa memiliki nilai rata-rata 83 . Dari hasil ini dapat dikatakan bahwa hampir seluruh siswa sudah menuntaskan belajarnya atau tuntas secara klasikal.

Keempat, kemampuan guru sudah sangat baik dan hasil belajar siswa cukup memuaskan karena guru dan siswa telah memiliki pengalaman dalam melakukan langkah-langkah pembelajaran problem based learning pada siklus I.

Berdasarkan uraian di atas dapat dikatakan bahwa hasil belajar sejarah siswa pada siklus II sudah cukup memuaskan, mencapai target $85 \%$ seperti yang diharapkan. Dengan demikian, 
penelitian tindakan kelas ini tidak perlu dilanjutkan pada siklus selanjutnya.

\section{Perbandingan Siklus I dengan Siklus II}

Perbandingan ketuntasan belajar sejarah siswa antara siklus I dan siklus II dapat dilihat pada tabel di bawah ini:

Tabel 1. Perbandingan ketuntasan siklus I dan siklus II

\begin{tabular}{|c|c|r|r|r|r|}
\hline \multirow{2}{*}{ No } & \multirow{2}{*}{ Keterangan } & \multirow{2}{*}{ S I } & \multirow{2}{*}{ S II } & \multicolumn{2}{|c|}{ Persentase (\%) } \\
\cline { 5 - 6 } & & & & \multicolumn{1}{c|}{ S I } & \multicolumn{1}{c|}{ S II } \\
\hline 1 & Tuntas & 14 & 21 & 58,3 & 87,5 \\
\hline 2 & Tidak Tuntas & 10 & 3 & 41,7 & 12,5 \\
\hline \multicolumn{2}{|c}{ Total } & 24 & 24 & 100,0 & 100,0 \\
\hline
\end{tabular}

Keterangan: S I (Siklus I) dan S II (Siklus II)

Berdasarkan tabel 1 di atas dapat dilihat bahwa siswa yang tuntas belajarnya pada siklus I berjumlah 14 orang atau 58,3\% dan pada siklus II terjadi peningkatan menjadi 16 orang atau $87,5 \%$. Sementara itu, siswa yang tidak tuntas belajarnya pada siklus I berjumlah 10 orang atau $41,7 \%$ dan di siklus II mengalami penurunan menjadi 3 orang atau $12,5 \%$.

\section{SIMPULAN}

Penerapan model problem based learning dalam pembelajaran sejarah di kelas XI IPS SMA Erlangga ternyata dapat meningkatkan minat belajar siswa. Siswa menjadi lebih aktif, berani bertanya dan mengungkapkan pendapatnya. Diskusi berjalan dengan baik sehingga suasana belajar menjadi "hidup" dan tidak monoton. Hal ini dikarenakan model problem based learning memberikan kesempatan kepada siswa untuk berpikir tentang pengalamannya. Bahkan siswa didorong untuk berpikir kreatif dan imajinatif, melakukan refleksi tentang model dan teori, serta mengenalkan gagasan-gagasan mereka pada saat yang tepat. Selain itu, model problem based learning dapat membuat lingkungan belajar yang kondusif sehingga mendukung siswa untuk mengungkapkan gagasan-gagasan mereka, saling menyimak dan menghindari kesan selalu ada satu jawaban yang benar.
Perencanaan pembelajaran sejarah dengan menerapkan model problem based learning memberikan motivasi berupa reinforcement ataupun reward sehingga dalam proses belajar mengajar dapat mengembangkan pemahaman bersama di antara guru dan siswa. Dengan menggunakan model problem based learning, proses pembelajaran sejarah dapat terarah dan sesuai dengan yang diharapkan.

Penerapan model problem based learning dalam pembelajaran sejarah di kelas XI IPS SMA Erlangga Pematangsiantar mampu meningkatkan hasil belajar siswa. Hal ini ditunjukkan dengan nilai yang diperoleh siswa pada setiap siklus. Pada siklus I, rata-rata nilai keaktifan siswa mencapai 71, sedangkan hasil belajarnya mendapat nilai rata-rata 69. Pada siklus II, nilai rata-rata keaktifan dan hasil belajar siswa mengalami peningkatan. Nilai ratarata keaktifannya mencapai 75 , sedangkan nilai rata-rata hasil belajarnya mencapai 80 .

\section{REFERENSI}

Arends, R. (2007). Learning to Teach (Seventh). New York: McGraw-Hill.

Arikunto, S. dkk. (2006). Penelitian Tindakan Kelas. Jakarta: Bumi Aksara.

Cozzola, M. (2008). Problem Based Learning and Mathematics: Possible Synergical Actions. In International Conference of Education, Research and Innovation. Valencia: ICERI.

Gagne, N. L. \& Buliner, David C. (2002). Educational Psychology (Third). Boston: Houghton MIFFPIN Company.

Hermawan, M. D. (2018). Pengaruh Model Problem Based Learning (PBL) dan Group Investigation (GI) dalam Pembelajaran Sejarah Ditinjau dari Motivasi Belajar di SMA Martapura. Istoria: Jurnal Pendidikan Dan Ilmu Sejarah, 14(1-11). https://doi.org/10.21831/istoria.v14i1.1940 0 . 
Hutauruk, A. F. (2014). Penggunaan Biografi Tjong A Fie dalam Menggali Nilai Multiluturalisme Peserta Didik pada Pembelajaran Sejarah; Penelitian Naturalistik dalam Pembelajaran Sejarah Lokal di Kelas XI IPS SMA Al-Ulum Medan. Universitas Pendidikan Indonesia.

Isjoni. (2007). Pembelajaran Sejarah pada Satuan Pendidikan. Bandung: Alfabet.

Kasbolah, K. (1998). Penelitian Tindakan Kelas. Malang: Departemen Pendidikan dan Kebudayaan.

Padmavathy, R. D. \& Mareesh. (2013). Effectiveness of Problem Based Learning in Mathematics. International Multidisciplinary E-Journal, 2(1), 45-51.

Purnamasari, I.\& Wasino. (2011). Pengembangan Model Pembelajaran Sejarah Berbasis Situs Sejarah Lokal di SMA Negeri Kabupaten Temanggung. Paramita: Historical Studies Journal, 21(2), 202-212. https://doi.org/10.15294/paramita.v21i2.1040.

Sagala, S. (2010). Konsep dan Makna Pembelajaran. Bandung: Alfabeta.

Sukadi. (2006). Guru Powerfull, Guru Masa Depan. Bandung: Kolbu.

Suryadi, A. (2012). Pembelajaran Sejarah dan Problematikanya. Historia Pedagogia, 1(1), 74-84.

Tan, O. S. (2009). Problem Based Learning and Creatifity. Singapore: Cenghage Learning Asia.

Tanjung, S. (2015). Pengaruh Media Pembelajaran dan Gaya Kognitif Terhadap Hasil Belajar Sejarah. Paramita: Historical Studies Journal, 25(2), 261-271. https://doi.org/10.15294/paramita.v25i2.5 170.

Usman, M. L. (2002). Menjadi Guru Profesional. Bandung: PT. Remaja Rosdakarya. 